\title{
Meaning of Education in the Bhagavad Gita
}

\author{
Janardan Ghimire* \\ Faculty of Education, Tribhuvan University, Kathmandu, Nepal
}

\begin{abstract}
Our academia is familiar with the educational theories and thoughts developed in the West. However, we have no adequate information about our own historical and cultural thoughts in relation to education, despite their importance and comprehensiveness. In the Bhagavad Gita, I noticed that some of the basic components of educational philosophy are present. Among the various aspects of educational thoughts, this paper deals with the interpretation of the meaning of education that can be found in the Bhagavad Gita. Interpretation of a comprehensive meaning of education consisted within the Bhagavad Gita can contribute to inspire academicians to look behind the curtain of history for searching valuable knowledge. It can also provide some bases for comparative study of educational philosophy in the East and the West. From methodological perspective, this paper is a product of an Arts-based hermeneutical interpretation of a historical scripture that has established interesting links to cultural practice, personal experiences and feelings of the author.
\end{abstract}

Keywords: Eastern wisdom tradition, the Bhagavad Gita, education, arts-based hermeneutics

\section{Enthusing about the Gita}

In my late childhood, I remember, my father would recite the Bhagavad Gita every morning. After evening meal, he would recite the scriptures like Mahabharata, Devibhagawad, Krishna Charitra, etc. translated into Nepali language, paying much attention to their rhyme, meter and verse sitting in front of the flame of a lamp. The climax of those stories used to fill me with varied emotions; sometimes they made me cry, sometimes laugh; sometimes they would render me emotional; and sometimes they filled me with delights. That influence developed in me an interest in reading the scriptures. When I was in the secondary school, my new companions' and teachers' statements and interactions, and closeness with the then underground communist leaders and cadres contributed in diminishing my interest in reading the scriptures. I started viewing my father's involvement in the reading scriptures to be a meaningless act. When I was in the course of completing my secondary education, I was becoming more negative towards religion, traditional cultural values and religious scriptures. Until I completed undergraduate studies, I understood the religious scriptures to be superstitious.

*Email: ghimirejanardan33@yahoo.com

ISSN: 2091-0118 (Print)/2091-2560 (Online) 
When I came to Kathmandu for the study of my master's degree, I started realizing that my worldview, my thoughts, attitude and knowledge were extremely narrow and imperfect in relation to my understanding of the Vedic scriptures. The course at this level demanded basic study of philosophy which made me realize that the Vedic philosophy and religious scriptures were very important to develop a multidimensional understanding of life and universe.

As a student of a teacher education program, I used to find several definitions of education in the textbooks. Our professors would also provide us with ideas and meaning of education through their instruction. I used to find almost all the definitions and meanings of education derived from the Western thoughts and theories. After entering the teacher education profession, I continued with the tradition and felt at home while teaching. I went through the ideas of Socrates, Aristotle, Plato and other prominent scholars in a process of introducing the meaning of education to my students. For example, education is a constant reorganizing or reconstructing of experience (Dewey, 1916, as cited in Westbrook, 1993); it is process of changing the behavior patterns of people (Tyler, 1949, p. 5); it is the acquisition of the art of the utilization of knowledge (Whitehead, 1929, as cited in Tanner $\&$ Tanner, 1980, p. 532). Despite that, a question that used to knock me constantly was about the Eastern wisdom tradition bereft of the meaning of education.

On completion of my master's degree, I got into the teaching profession as a university lecturer. I tried to use some free time in reading the Bhagavad Gita but I could not pay adequate attention. To give continuity to the study of the Bhagavad Gita and to make my reading intelligible, I collected several materials written in Nepali, English and Hindi that interpreted the meaning of the Bhagavad Gita. I began to see pedagogical dimension of the Bhagavad Gita. When I sat in the MPhil classes listening to the professors specially discuss the Western philosophy, those discussions, I felt, resembled the interpretations of the Bhagavad Gita. And my imperfect and incomplete study of the Bhagavad Gita kept me motivated towards its further study. I observed some ideas of the Western thinkers to know what they think about the Vedic thoughts. I found Frauwallner (1973) argue that the Vedic philosophical tradition is older than the Greek civilization. This added fuel to the fire that was burning inside me and a quest drove me to ponder into the Eastern myths and mythologies.

I found that many scholars in both the East and the West seem to be interested in studying and interpreting the educational aspect of the Bhagavad Gita. A Vedic scholar, Prabhupad (1986) argues that the Bhagavad Gita is a popular source of knowledge and wisdom for the global community (as cited in Bhawuk, 2011, p. xxii). Similarly, Fosse (2007), a scholar from the West, writes "the Bhagavad Gita still speaks to people everywhere - across the ocean, across the millennia, and across the boundaries of the language religion and the culture" (p. xxiv). Based on these arguments, it can be said that the Bhagavad Gita is a comprehensive philosophical thought for all humankind. It intervenes with a restatement of the truth of the Spirit, of the Self, of God and of the World and Nature. It extends and remolds the truth evolved by a later thought from the ancient Upanishads and ventures with assured steps on an endeavor to apply its solving power to the problem of life and action (Leaman, 2000, p. 40). In this sense, it is also directly connected with the nature and life. 
So, I felt, we need to look at it through the philosophical eye. In its deep meaning, we can get comprehensive philosophical thoughts and theories, for example, Metaphysics, Epistemology, Axiology and Logic System. Likewise, we also can draw some educational thoughts. Worthily saying, I found interesting educational philosophical thoughts in the verses of the Bhagavad Gita (e.g. aims, meaning, and importance of education, teaching subjects and methods, ways of motivating learner, etc.). On this background, I have tried in this paper to deal with the meaning of education that can be found in the Bhagavad Gita.

This article is based on my MPhil dissertation carried out in 2012 at Kathamandu University, School of Education. The study was based on the interpretative paradigm under an Arts-based hermeneutic design (Thompson, 1997; Frazier, 2008) as the method of the study for the reason that I found it more appropriate for generating data from the text and also for creative interpretation of the text. So, my journey began with a collection of related texts. I reviewed the main text of the Bhagavad Gita as well as its interpretation by various scholars, and the Upanishads. I generated data adopting several hermeneutical reading cycles. After data generation, I interpreted my understanding using Arts-based method (Taylor, Settelmaier, \& Luitel, 2012; Barone \& Eisner, 2012).

My study revealed that the Bhagavad Gita can be taken as an ocean of philosophical thoughts of the Eastern wisdom tradition. It would be injustice if we looked at the Bhagavad-Gita only through the lens of religious myth. We need efforts for bringing out the hidden knowledge form our scriptures and use this knowledge for improving our education sector. However, no serious attention has been paid to this philosophy in our society and universities. This may be because of the fact that our education system has grown on the feed of the Western thoughts. I do not mean the Western thoughts are not useful; my emphasis is on the search and dissemination of our own historical knowledge.

\section{The Bhagavad Gita: A Sublime Thought}

I understand the Bhagavad Gita as a poetic narrative in the form of a conversation between Krishna and Arjuna on the battlefield of Kurukshetra just prior to the start of the climactic Kurukshetra War. It, sometimes called "The Lord's Lay," or the "Message of the Master," is an episode of the Mahabharata. It is considered to be one of the greatest scriptures of the Vedic philosophy. It offers a synthesis of many existing Vedic teachings within an overall framework of belief in God (Thompson, 2011, p. 14). In my understanding, the Bhagavad Gita shows the ways to live a spiritual cum material life consequently.

It contains within it, the distilled essence of the Upanishads, which encourages us to manifest total excellence in all that we do, and in all our relationships by discovering the latent divinity within us (Tilak, 1959). It attempted synthesis of its proto-Shankhya and Upanisadic Vedanta concepts (White, 1979). Although the Bhagavad Gita is conceived as an essence of all Vedic philosophical thoughts, no reference in its entire text claims that it is for the Hindus. So, it can be said that it is for 
all humankind throughout the world. In this sense, it is always of great importance to all. It is one of the three central texts of the Vedanta, the other two being the Brahma Sutras and the Upanishads (Fosse, 2007, p. ix). The Bhagavad Gita is also a key authority (Bartley, 2011, p. 134). Adhikari (2044 B.S.) argues that the Upanishads are for the authorized persons, the Brahma-sutra is for scholars (because others might not understand it easily) but the Bhagavad Gita is appropriate for all. It is not for some specific community, caste, creed, sex, country but it is a common asset of all human beings. It is also known as the Gitopanisad. It is the essence of Vedic knowledge and one of the most important Upanishads in the Vedic literature (Swami, 1971). Tilak (1959) interpreted that-among all religious scriptures, the Bhagavad Gita is the brightest and the purest diamond. In the view of Khatiwada (2066 BS), the holy Gita is the essence of the Vedas, the Upanishads and these scriptures deal with Paravidya (Brahma Vidya) and Aparavidya (Karma Pradhan Vidya). The Bhagavad Gita has exercised an influence on the widest circle more than any other religion (Frauwallner, 1973, p. 77).

In my understanding, it is a universal scripture applicable to people of all temperaments and for all times. It is a book with sublime thoughts and practical instructions on the Yoga, devotion, and action. It is profound in thought and sublime in heights of vision. Even though the Bhagavad Gita was created on the battlefield before the commencement of the war, its relevance in present context is still meaningful and considerable. Therefore, the battlefield represents our body where an unending battle is raging between good and evil forces.

\section{Meaning of Education in the Bhagavad Gita}

In my understanding and experiences, education is the process of cultivating completeness in human being. That implies knowledge, skill, ability and wisdom for Karmic and Dharmik life. Perhaps, our wisdom tradition supports me. In the view of Radhakrishnan and Moore (as cited in Bhawuk, 2011, p. 164), the Bhagavad Gita is a synthesis of all Vedic ideas and wisdom and it was developed through the instructional process. It may be looked upon as a discourse addressed by a Guru to a Chela who has fully determined upon the renunciation of all worldly desires and aspirations but yet feels certain despondency, caused by the apparent blankness of his existence (Rao \& Bannerji, 1912, p. 2). Marsella (as cited in Bhawuk, 2011, p. 24) sees the Bhagavad Gita as a psychology of the Eastern civilization. While the Bhagavad Gita is known as an instructional module, the philosophy of life and psychology obviously has the meaning of education.

In the beginning of my reading, I was not able to find anything related to the meaning of education. I followed several hermeneutic circles of reading and though I smelt some fragrances, yet did not grasp the direction. After the intensive reading, I found it to have occupied a significant space as a module of instruction during my professional journey. In my understanding, knowledge, wisdom, action and devotion are the main focus of the Bhagavad Gita. It can be interpreted associating these four subjects with the meaning of education. According to the philosophy of the Gita, the 
state when a human is free from the three wraths (lust, anger and fear), is the state of attainment of knowledge and wisdom (Bhagavad Gita, 2.56).

दु:ख्वेष्वनुद्विग्नमनाः सुखेषु विगतस्पृहः ।

वीतरागभयकोधः स्थितधीर्मानिरुच्यते ॥ २-५६॥

One who is not disturbed in mind even amidst the threefold misery or elated when there is happiness, and who is free from attachment, fear and anger, is called a stage of steady mind.

The state when one reaches to the steady wisdom has been called the state situated with the knowledge. Therefore, the Bhagavad Gita provides very useful and practicable 'contents' for education that can address the problems related with action, salvation and wisdom. Hence, education on salvation, education on action and education on wisdom seem to be more relevant aspects of the Bhagavad Gita. A question can be raised: what is meant by steady wisdom? I understood, the Bhagavad Gita states that the state of steady wisdom is such a state when achievement and failure, profit and loss, joy and sorrow can be perceived in equal terms (Bhagavad Gita, 2.57), that is a state of the fullest satisfaction or the end state of desires.

यः सर्वत्रानभिस्नेहस्तत्तत्र्राप्य शुभाशुभम्।

नाभिनन्दति न द्वेष्टि तस्य प्रज्ञा प्रतिष्टिता ॥ २-५७॥

In the material world, one who is unaffected by whatever good or evil he may obtain, neither praising it, nor despising it, is firmly fixed in perfect knowledge.

There is always satisfaction when one takes in the self or self- realization (Bhagavad Gita, 3.17). Question of motivation and demotivation can be raised again. Bhawuk (2011) viewed that "we see that the Bhagavad Gita defines the purpose of work - work is to be performed for its own sake, not for its outcomes (p. 148). In my understanding, the steady wisdom itself is taken as motivation for right action and it can also be conceived as the concept of education. Again one can ask - is this state possible in the material world? This question demands multiple answers. Perhaps, the intended meaning may be that one should not be overjoyed by the achievement, profit and happiness and extremely grieved in the contrary situation. I mean, materialistic pleasure is temporary, can be lost any time but steady wisdom never drags us toward loss. This state may be a stable emotional condition, stability in thinking and action, freedom and a self directed state. Aren't these states essential for a holistic personality? Can this state not beinterpreted as education? Can stability of life not be taken as education? In my

नियतं सदुराहितमरागद्वेपतः कृतम्.।

अफलग्रेप्सूना कर्म यत्तत्साच्चिकमूच्यते ॥ १८-२३॥

That action which is regulated and which is performed without attachment without love or hatred, and without desire for fruitive results is said to be in the mode of goodness.

यत्तु कामेम्सुना कर्म साहंकारेण वा पुनः ।

क्रियते बह़लायासं तद्राजसमदाहतम ॥ १८-२४॥

That action which is regulated and which is performed without attachment without love or hatred, and without desire for fruitive results is said to be in the mode of goodness.

view, stability is a component of wholeness. The Bhagavad Gita states that one who performs an action with controlled mind and wisdom is wise. On the basis of this 
discussion, the control in mind and wisdom can be linked with the meaning of education. To annihilate doubts, to attain salvation, to perform duties according to the suggestion of the scriptures and to understand the advice of the Bhagavad Gita can be linked with the meaning of education.

In my understanding, the Bhagavad Gita teaches us to be Dharmik in adherence to social and ethical responsibilities (Bhagavad Gita, 4.7, 8.3, 18.7, 18.14, 18.23-24). Understanding of Leaman (2000) on the Bhagavad Gita also supports me. He argues that "the Gita's message to the mind occupied with the pursuit of intellectual, ethical and social standards, the mind that insists on salvation by the observance of established Dharmas, the moral law, social duty and function or the solutions of the liberated intelligence" (p. 41). I don't think I am in the capacity to perfectly figure out all Dharmik elements that have been prescribed and stated in the Bhagavad Gita, because, my mind, orientation, and level of understanding were conditioned to interpreting it from the educational perspective throughout my reading circles. Nonetheless, I can easily say that to live a Dharmik (morality, accountability, righteousness and commitment in one's duty) life can be associated with education according to the Bhagavad Gita and such an education makes human Dharmik thereby developing capacity to raise voice against injustice of any sort, involve in welfare of living beings, be impartial to truth and discern between what is human and what is inhuman.

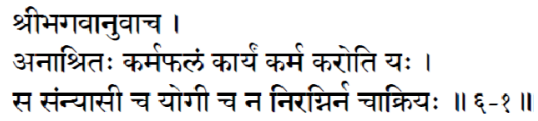

The supreme personality of Godhead said: One who is unattached to the fruit of his work and who works as he is obligated is in the renounced order of life, and he is the true mystic, not he who lights no fire and performs no duty.

युअन्नेवं सदात्मानं योगी विगतकल्मपः ।

सुखेन बह्मसंस्पर्शमत्यन्तं सुखमश्नुते ॥ ६-२८॥

Thus the self controlled yogi, constantly engaged in yoga practice, becomes free from all material contamination and achieves the highest stage of perfect happiness in transcendental loving service to the lord.

The Bhagavad Gita gives emphasis on the right duty known as Karma yoga. Bhawuk, (2011) states "the Bhagavad Gita recommends the practice of Karma Yoga, or the path of work (or doing one's prescribed duties), as the intervention to avoid the unhappiness resulting from the pursuit of desires. This is done through manan and chintan or self-reflection and contemplation" (p. 117). According to Gupta (1922):

The Bhagavad Gita tried to mark out a middle path between the austere discipline of meditative abstraction on the one hand and the course of duties of sacrificial action of a Vedic worshipper in the life of a new type of Yogi on the other, who should combine in himself the best parts of the two paths, devote himself to his duties, and yet abstain himself from all selfish motives associated with desires. (p. 469)

These statements show teaching of the Bhagavad Gita gives emphasis on combination of mental, physical and spiritual (socio-cultural) paths of education which are very much focused aspects in the modern psychology as well. The Bhagavad Gita identifies this combination as yoga and I feel that that is the process of perfection. 
Prabhupad postulates, "The Bhagavad Gita shows how our physical self is related to work" (as cited in Bhawuk, 2011, p. xxiv). And his belief is not devoid of modern aspects of psychology either. These views of scholars reveal that karma yoga is one of the major teachings of the Bhagavad Gita, which seems completely based on the tested psychological facts. In my understanding, karma yoga is the thought and action which is guided through wisdom. That wisdom also seems to be connected with the concept of education.

The term salvation seems to be the purpose of the teaching of the Bhagavad Gita (Bhagavad Gita, 2. 15, 51; 5. 17, 19, 25, 26, 7:14, 13:24, 18: 51-53).

बुद्या विशुद्दुया युक्तो धृत्यात्मानं नियम्य च।

विविक्तसेवी लघ्वारी यतवाक्कायमानसः।

अहंकारं बलं दूर्प कामं कोधं परिग्रहम्।

राब्द़ाद़ीन्विषयांस्त्यक्का रागद्वेषौ व्युद्स्य च ॥ १८-५१॥ ध्यानयोगपरो नित्यं वैराग्यं समुपाश्रितः ॥ १८-५२॥ विमुच्च निर्ममः शान्तो वह्मभूयाय कल्पते ॥ १८-५३॥

Being purified by his intelligence and controlling the mind with determination, giving up the objects of sense gratification, being free from attachment and hatred, one who lives in a secluded place, who eats little, who controls his body, mind and power of speech, who is always in trace and who is detached, free from false ego, false strength, false pride, lust, anger and acceptance of material things, free from false proprietorship, and peacefulsuch a person is certainly elevated to the position of self-realization.

The Bhagavad Gita indicates that the state of purified and controlled mind, purified intellect, strong determination and lost state of false ego, pride, anger, greed is the position of self- realization. Position of self-realization is the situation of Vidya that is education. So, it can be interpreted as an important principle related to the meaning of education. A contradiction appears here - how can it be said that the thing related with salvation has implication in the present world, too? Perhaps, Marxists take salvation as to gain ownership over the means of production, capitalist may conceive it as the contrivance to accumulate more and more goods and money for a comfortable and joyous life, and an orthodox may understand his/her religion as realization of the God or blessing of God. We have to take salvation in a broader sense. Every human in this world is in need of salvation. Students in schools are in need of salvation from fear, terror and punishment of teachers and pressure from parents. Other people involved in different activities are in need of salvation from violence, conflict, pride, ego, tension, poverty, ignorance, etc. The sick are in need of salvation from diseases and older people from death. Those who want to practice renunciation are in need of salvation from family. All these people are in need of salvation from the type of experience they are gaining. I felt that, salvation as stated by the pieces of advice of the Bhagavad Gita is not other than these all. The verse (5.26) of the Bhagavad Gita supports me that "those who are free from anger, who are self-realized, self disciplined and constantly endeavoring for perfection, are assured of liberation in the Supreme in the very near future." Therefore, in my understanding, salvation can easily be incorporated with the meaning of education.

On the basis of the above discussion, I think, it will be significant if I could brief the meaning of education and impressively step on the premises of the Gita philosophy. But it is equally challenging to reach a universal meaning of education. The meaning of value based education might take its root in spirituality and materialistic definition might origin from the worldly phenomenon that surrounds us every day. I suppose a single most definition as such might not suffice to what I am trying to 
explore. Therefore, I am of the opinion that it would be better to strike on a broader perspective. In this connection, Bhawuk's (2011) argument highlights that the Bhagavad Gita describes the possibility of a state in which we can actually rise above cognition, emotion, and behavior and presents karma yoga as a process to achieve this state (state of salvation)" (p. 118). This notion provides me with some ideas to synthesize the teachings of the Bhagavad Gita to trace the meaning of education accordingly. In a concise sentence, being based on my own understanding, after (in fact perennial) reading the Gita repeatedly and analyzing the scholars' notions, it can be said that: Education (Vidya) is the process of performing one's own duties for the attainment of peace, joy, satisfaction and salvation being rid of the three wraths (lust, anger and fear) with the steady mind and wisdom.

The word "Vidya" has been used in the Bhagavad Gita to introduce the realm of education and knowledge. Mainly two types of knowledge have been discussed in the Bhagavad Gita - logical knowledge (i.e. rational, academic and standard or materialistic) and spiritual knowledge. The logical knowledge has been identified as the ability to discuss the external form of things available in the world through wisdom perceiving them with the senses. The logical knowledge has been called the 'Science' (the Bhagavad Gita, 5. 8-9, 9.6, 13.3).

क्षेत्रज्ञ चापि मां विद्दि सर्वक्षेत्रेषु भारत ।

क्षेत्रक्षेत्रज्ञयोर्जानं यत्तज्ञानं मतं मम ॥

Bharata! You should understand that I am also the knower in all bodies, and to understand that body and its knower is called knowledge. This is my opinion.

The knowledge of the internal aspects (Soul, the Brahma or Supreme-Soul) of matter and creatures has been called the spiritual knowledge. I have come to know that Vidya and Avidya have also been discussed in the mantras of the Iswasyopanishad (Iswasyopanishad, verses 9-14, as cited in Acharya \&Sharma, 2010, p. 36). The actions which are performed for the attainment of various types of comforts, luxury, prosperity or joy have been called Avidya and the actions performed for the attainment of the Brahma (self-actualization or soul realization) have been called Vidya. It means education is essential both to eke out the material life and attainment of spiritual upgrading. Doesn't it sound (ir)rational? It expresses that Avidya (action or materialistic knowledge) and Vidya (spiritual knowledge) should go together. Spiritual education might not be misinterpreted. In our context, spiritual education should not necessarily be based on the literal reading of the scriptures and the appreciation of the Gods, their charisma and their savior nature but it may be an appropriate remark to make that the way Ram, Laxman, Arjuna, Yudhisthira, etc. were attuned to knowledge, skills, attitudes, dharma and wisdom by their gurus. Perhaps, this way might be meaningful to cultivate a holistic personality even in the present context. However, we should not forget that we are living at the age of hyper technology and a 'teacher' can become a 'guru' only after severe toil in favor of the students. While saying this what I mean is spiritual education (and knowledge) can make the students meditative, soul-searching, self-exploring and showing equal concerns and empathy to all the beings and their own and others' welfare. 
So, the meaning of education as can be identified in the Bhagavad Gita highlights this prominent aspect of human being as well. It has been stated in the Veda Shukta that "Immortality (salvation) can be attained through Vidya (spiritual education), it is possible to gain victory over death / lengthening the life through Avidya (actions or material education) and acquire nectar/ salvation (amrita) through Vidya" (Yajurveda, 40. 14). What I can say on the basis of this discussion is that the Bhagavad Gita has not called only the spiritual knowledge as education instead it has taken both spiritual and material aspects in defining education. In this way, the Bhagavad Gita has considered education as the basis for worldly and spiritual progress.

\section{Conclusion}

After reading the Bhagavad Gita, I came up with the understanding that it is our valuable historical asset of knowledge, and it demands deep study and interpretation. The moral teaching, specially ethical actions that run through the whole of the Bhagavad Gita is not only an emergence need of our country, but of the world community. Even though it is conceived as a religious scripture, it can be a source of much philosophical and psychological insight to study human life, universe, nature, cognition, emotion, and behavior, as well as education. We can enrich our philosophical, sociological, anthropological and psychological understanding through the readings of the Bhagavad Gita. In the Bhagavad Gita, much effort has been made to equate Karma Yoga, Gyan Yoga, and Bhakti Yoga, in which meaning of education fragranced. One can get fruit from the Bhagavad Gita according to his/her intention and level of understanding. For me, the Bhagavad Gita identifies moral duties, harmonious ethical climate, unity between spirituality and practice, between the transcendental and the material living. Through the lens of education, all aspects of educational philosophy, i.e. meaning of education, aims of education, importance of education, learning materials, pedagogy, curriculum, motivational techniques, assessment practice, and roles of learner and teacher can be found and interpreted by and through a deeper reading of the Bhagavad Gita. Therefore, the Bhagavad Gita can be taken as an educational philosophy, because it has got all components of an educational philosophy. For the purpose of making meaning of education from the Bhagavad Gita, the Vidya is a major concept. Performing one's own duties for the attainment of joy, satisfaction and salvation getting rid of the three wraths (lost, anger and fear) with the steady mind and wisdom is the true meaning of Vidya/ education found in the Bhagavad Gita.

\section{References}

Acharya, S. R., \& Sharma, B. D. (Eds.). (2010). 108 Upanishad, gyan kanda. Mathura, Gayatri Tapobhumi: Uga Nirman Yojana Bistar Trust.

Adhikari, A. (2044 BS). Shreemadbhagavad Geeta, Geeta lokbhasya. Kathmandu: Loklaxmi Adhikari.

Barone, T., \& Eisner, E. W. (2012). Arts based educational research. Los Angeles: SAGE.

Bartley, C. (2011). An introduction to the Indian philosophy. London: Continuum International Publishing Group. 
Bhawuk, D. P. S. (2011). Spirituality and Indian psychology: Lessons from the Bhagavad-Gita. New Delhi: Springer.

Fosse, L. M. (2007). The Bhagavad Gita: The original Sanskrit and translation. Retrieved from http://www.goodreads.com/review/show/99876257

Frauwallner, E. (1973). History of Indian philosophy (Vol.1): The philosophy of the Vedas and of the epic- the Buddha and the Jain - the shankhya and the classical yoga system (V. M. Bedekar, Trans.). New Delhi: Motilal Banarsidass.

Frazier, J. (2008). Hermeneutics in Hindu studies. The Journal of Hindu Studies, 1, 3-10.

Gupta, S. D. (1922). A history of Indian philosophy (Vol. I). New Delhi: Cambridge. Khatiwada, B. (2066 BS). Upanishad: Samkshipta awalokan. In B. Mohonpradad, \& D. Bhumiprasad (Eds.), Purvia chintan parampara (pp. 20-30). Kathmandu: Vidharthi Publication.

Leaman, O. (2000). Eastern philosophy: Key readings. London: Routledge.

Rao, T. S., \& Bannerji, N. K. (1912). On the Bhagavad-Gita, (17). Chennai: Theosophical Publishing House.

Swami, B. (1971). Bhagawad Geeta as it is. Chicago: University of Chicago.

Tanner, D., \& Tanner, L. N. (1980). Curriculum Development: Theory in to Practice. New York. Macmillan Publishing Co. Inc.

Taylor, P. C., Settelmaier, E., \& Luitel, B. C. (2012). Multi-paradigmatic transformative research as/for teacher education: An integral perspective. In K. Tobin, B. Fraser, \& C. McRobbie (Eds.), Second international handbook of science education (pp. 373-388). Dordrecht, The Netherlands: Springer.

Thompson, C. J. (1997). Interpreting consumers: A hermeneutical framework for deriving marketing insights from the texts of consumers' consumption stories. Journal of Marketing Research, 34(4), 438-455. Retrieved from http://www. jstor.org

Thompson, M. (2011). Teach yourself eastern philosophy. Retrieved from http://www. philosophyandethics.com

Tilak, B. G. (1959). Shreemad Vagawad Geeta rahasya athawa karmayog shastra. Pune: Jayant Shreedhar Tilak.

Tyler, R. W. (1949). Basic principles of curriculum and instruction. Chicago: University of Chicago press.

Westbrook, R. B. (1993). John Dewey (1859-1952). International Bureau of Education, 23(12), 277-91.

White, D. (1979). Proto-shankhya and advaita vedanta in the Bhagavadgita. Philosophy East and West, 29(4), 501-507. Retrieved from http://www.jstor.org/ stable/1398818 